\title{
An Econometric Analysis of Holdup Problems in Construction Projects
}

\author{
Chen-Yu Chang ${ }^{1}$ and Yaming Qian ${ }^{2}$
}

\begin{abstract}
The holdup problem plays a central role in explaining governance choices in general and project delivery system selection in particular. This problem arises because of the asymmetrical distribution of quasi-rents between two trading parties. To put this theoretical proposition to a direct test, this research first uses the Nash bargaining model to derive a hypothesis that links quasi-rent differences to the excess profit margin that the contractor can achieve in ex post negotiations, and then collates a data set of 62 change-order cases to enable the hypothesis to be tested econometrically. The corroboration of the hypothesis lends empirical support to the core argument used in the analysis of construction holdup problems. This finding brings to the foreground the significance of recognizing that change orders might be attributed to the owner's strategic choice. Ignorance of this factor would bias the coefficient estimation in the empirical analysis of change orders. DOI: 10.1061/(ASCE)CO.1943-7862.0000957. This work is made available under the terms of the Creative Commons Attribution 4.0 International license, http://creativecommons.org/licenses/by/4.0/.
\end{abstract}

Author keywords: Change orders; Transaction cost; Holdup; Quasi-rent; Bargaining power; Contracting.

\section{Introduction}

Construction procurement involves a process in which the inputs from different participants are coordinated to produce a physical asset in accordance with the owner's requirements. The efficiency of the contracting process depends not only on how hard project participants have worked towards the owner's interest, but also on the way that project surplus is divided among parties exposed to various risks. In traditional design-bid-construction systems, the owner leverages price competition to drive down the contractor's "promised" cost ex ante and steps up monitoring to secure the achievement of this promise ex post. History evinces that this "squeeze-and-protect" strategy has led to excessive sources being applied to litigation (Latham 1994). A major cause of dispute stems from the contractor's tendency to exploit the owner's bargaining disadvantage in the postcontract stage owing to the presence of appropriable quasi-rent (AQR) (Chang 2013b; Chang and Ive 2007b). It is the origin of the well-known holdup problem in the construction context. Change orders are prevalent in construction projects (Finkel 1997; Sun and Meng 2009). The occurrence of a change order would damage the trust base between the parties if the price charged by the contractor is perceived to be "exorbitant" (Masten et al. 1991). As suggested by the Coase theorem, making postcontract changes should not be a problem if frictionless bargaining can be achieved to ensure that trading parties agree on the deal that maximizes the joint interests of both parties (Farrell 1987). Perfect information, an underlying assumption of frictionless bargaining,

${ }^{1}$ Lecturer, Bartlett School of Construction and Project Management, Univ. College London, 1-19 Torrington Place WC1E 7HB, London (corresponding author). E-mail: chen-yu.chang@ucl.ac.uk

${ }^{2}$ Master Student, Bartlett School of Construction and Project Management, Univ. College London, 1-19 Torrington Place WC1E 7HB, London. E-mail: qym280@live.cn

Note. This manuscript was submitted on August 7, 2014; approved on November 7, 2014; published online on January 19, 2015. Discussion period open until June 19, 2015; separate discussions must be submitted for individual papers. This paper is part of the Journal of Construction Engineering and Management, (C) ASCE, ISSN 0733-9364/04015004(8)/ $\$ 25.00$. can also make it feasible to implement theoretical solutions to holdup problems by assigning full bargaining power to one party through a contract (Aghion et al. 1994; Chung 1991). However, in most real-life scenarios where traders face severe information incompleteness, this contractual solution cannot be enforced by the third party; thus, renegotiation still needs to be called upon to resolve the pricing of new orders. Whereas the ex post adaptability problem has occupied the central place in the theory of organizational economics (Baker et al., unpublished data, 2011), the empirical test is mostly focused on the connection between governance choices and relevant determinants. There is a lack of direct evidence of whether AQR can really serve as a good predictor for the outcome of postcontract negotiations. This research fills this gap by delving into the contracting process through developing a testable hypothesis using the Nash bargaining model and investigating the impact of the difference in profit margins achieved ex post and ex ante by the contractor. The statistical link found lends support to the core argument of an expanding body of literature on construction holdup problems (Chang 2013a, b, c; Chang and Ive 2007b).

This research also has implications for the study of change orders. While this common problem in construction has been heavily investigated by project/construction management researchers, the existing works have mostly focused on the statistical relationship between change order causes and their impacts on the contract price. Nonetheless, according to an immediate corollary of this research, change orders may be due to the owner's strategic choice, which would in turn affect the typical causes of change orders (such as unforeseen work and quantity differences). Giving no consideration to this factor will result in a biased estimation of coefficients. To resolve this so-called endogeneity problem in econometrics (Wooldridge 2010), it is useful to advance the study of change orders by developing a behavioral model on the basis of organizational economics or behavioral economics. An amalgamation of the rigor of economic approaches into engineering management research would prove to be a fruitful way forward. 


\section{Literature Review}

This research is related to two strands of literature. The first is associated with transaction cost economics (TCE) and its application to construction contexts. A major contribution of TCE is bringing the dynamism of the trading relationship to the foreground by emphasizing "the effect of transforming what may have been a large numbers bidding competition at the outset into a small numbers exchange relationship during the period of the contract and at the contract renewal interval" (Williamson 2010). In this transformation process, what is evolving is the trading parties' bargaining power. Prior to signing a contract, the owner can harness competitive mechanisms to elicit the best offer from the market. However, once the contract is signed, the owner's capital [in the form of liquid assets (e.g., cash)] is gradually converted into the physical asset, which has a much lower value outside the contract than within it. In the event of premature contract termination, the owner will incur a large loss as a result of the forced sale of the half-completed asset, and thus would be willing to accept a less desirable offer in postcontract negotiations than when dealing with competition. The presence of bargaining power reversal will make the owner lose the flexibility to make changes at reasonable prices (Chang and Ive 2007a). As demonstrated in voluminous TCE empirical studies (Macher and Richman 2008; Shelanski and Klein 1995), the presence of the holdup threat has a profound implication for canonical governance choices (e.g., make or buy decisions). It is also found to be crucial to the choice of project governance (Ive and Chang 2007; Winch 2001). Different from the typical holdup setting (Chang and Ive 2007a), Unsal and Taylor (2010) studied a holdup problem occurring in the precontract stage as a result of the lock-in effect arising from the main contractor's sunk investment in interorganizational learning. The decision-making context is as such: in each period, the main contractor elicits sealed bids from two subcontractors. The main contractor chooses a subcontractor to minimize the sum of "boundary cost" and subcontract price. The boundary cost, which seems meant to capture the coordination cost of joint working between two parties, is assumed to decrease exponentially following a learning curve (i.e., the more times that subcontractors have worked with the main contractor, the lower the cost). It is also assumed that the subcontractor types that differ in boundary cost are common knowledge in bidding, and the opponent's boundary cost is factored into one party's bidding price. Applying a game-theoretic bidding model developed by Criesmer et al. (1967), the effects of learning on coordination cost and bidding behavior are integrated. The main contractor faces the choice of two strategies: selecting the subcontractor with the lowest total cost, or switching partners for each of the first three projects. The key finding is that where there are high task dependencies, subcontractors show a stronger tendency to overprice the work, making it more desirable to switch subcontractors more often.

The second body of literature is concerned with the causes and management of change orders. Hsieh et al. (2004) investigated 90 Taiwanese public projects in order to identify the causes of change orders by probing the chains of events. Of nine categories of change-order causes, flawed planning and design are ranked as the most serious contributor to contract price increase on the basis of an ANOVA analysis. Wu et al. (2005) examined the changeorder cases in Taiwanese highway projects, finding that inadequate geological survey is the major cause of change orders. Ibbs (2005) analyzed 162 projects to explore the impact of the issuance timing of change orders on labor productivity, confirming that the later that changes were made, the greater the impact. Generally, the statistical methods employed in these works are not sophisticated enough to ascertain the robustness of their findings. With no attempt to separate out the effect of other factors, these results should be read with caution. Relatively, Serag et al. (2010) is an improvement in the sense that they utilized multiple regression to filter the effects of 11 factors on the increase in contract price and ranked the importance of these factors in terms of the $p$-value of each factor's estimated coefficient. It was found that the top three factors are timing of change orders (the later that change orders are issued, the larger their impact on the price increase), quantity variations, and occurrence of unforeseen events.

The line of reasoning implicit in the existing analysis of change orders (Mitropoulos and Howell 2001; Serag et al. 2010; Wu et al. 2005 ) is that postcontract changes cause cost escalation, and hence the reasons for these changes should be carefully diagnosed to reduce their recurrence. Nevertheless, on a priori ground, change orders may arise as a result of the owner's strategic decision. For instance, time pressure might force the owner to put the project for tender before the technical design is fully completed. This type of change order is of a different nature from the type that results from uncertainty (e.g., design errors and unforeseen underground conditions) (Chang and Ive 2003). As will be discussed later in this paper, conflating these two types could lead to a bias in statistical analysis.

\section{Development of Hypotheses}

Generally, change orders happen due to one of two generic reasons: value creation or loss prevention. On the one hand, the owner may find it desirable to change the design to increase the value of the assets after the project is let. On the other hand, change orders may become necessary in situations where unforeseen events occur as a result of design omission, contingency, or policy changes. While change orders are omnipresent in construction projects, the pricing behavior in the negotiation of change orders is not well studied. It is useful to put it to rigorous scrutiny in a formal model.

At a point in time $(t)$ during the construction stage, an unexpected event occurs. If the project does not change, the event would result in a substantial loss to both the client and contractor. An example of this scenario is the incidence of extremely poor ground conditions. Without making design changes, the owner will bear a large loss, as the building is no longer safe to erect. The contractor will suffer as well, because it costs much more to prevent health and safety accidents while building the foundation. For this reason, initiating a change order may yield an efficiency gain. The construction cost of the new work $(C)$ is made up of the central estimate $(c)$ and a uniform random variable $w$ ( $l \geq w \geq-l$, with $l$ constant). The new work can create a benefit $v$ for the owner. This means that the expected surplus of this change order can be calculated as

$$
S=v-c
$$

The question of interest is how great a profit margin the contractor can achieve in pricing this work, given the bargaining position of two parties at $t$.

When it comes to bargaining, Nash (1950) provided a powerful modeling option. In the standard general setting, two players $(i=1,2)$ negotiate over the division of a monetary reward $(\Delta s)$ to advance their individual wealth $\left(s_{1}, s_{2}\right)$ from the status quo point $\mathrm{D}$ (also known as the disagreement point or threat point) to point $\mathrm{B}$ $\left(s_{1}^{*}, s_{2}^{*}\right)$ (Fig. 1). The bargaining outcome (i.e., point B) will be determined by maximizing the Nash product $(U)$, indicated by the hyperbola frontier in Fig. 1; i.e.

$$
\operatorname{Max}_{s_{1}, s_{2}} U=\left(s_{1}-d_{1}\right)\left(s_{2}-d_{2}\right)
$$




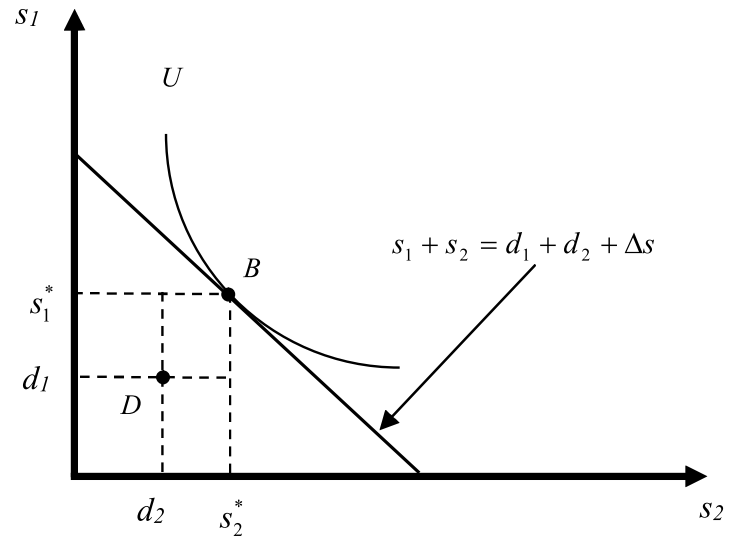

Fig. 1. Nash bargaining model

$$
\text { subject to }\left(s_{1}-d_{1}\right)+\left(s_{2}-d_{2}\right)=\Delta s
$$

The choice of the threat point holds the key to incorporating the details of the applied context (Binmore et al. 1986). Suppose that the interest at stake is so large that two parties would consider walking away from the contract altogether if the negotiation for the change order breaks down. The extent of the downside risk that one party would withstand can be measured by the quasi-rent (Chang 2013a, 2014). Quasi-rent indicates the return that one trader requires in excess of the minimum to stay in the contract (Milgrom and Roberts 1992). If both parties cannot reach an agreement, the contractor would rather incur a loss equal to his or her quasi-rent $\left(Q_{c}\right)$ by backing out of the contract than bear the blunt of the unforeseen cost shock. Similarly, the client would prefer to change the contractor in the event of a negotiation breakdown. As a result, the pair $\left(Q_{o}, Q_{c}\right)$ can be treated as the disagreement payoff for this change-order negotiation.

Following the tradition of the Nash bargaining model, it is assumed that the cost and benefit of change orders are common knowledge for both the owner and the client in bargaining. While the assumption of symmetric information has been widely used in economic modeling (Grossman and Hart 1986; Hart 1995; Hermalin and Katz 1991), this research only includes lowcomplexity projects in the data set to minimize the influence of this assumption on the result.

All together, the bargaining problem can be formulated as follows:

$$
\begin{gathered}
\underset{s_{1}, s_{2}}{\operatorname{Max}}\left(s_{o}+Q_{0}\right)\left(s_{c}+Q_{c}\right) \\
\text { subject to } s_{o}+s_{c}=S
\end{gathered}
$$

The solution can be easily found

$$
s_{o}=\frac{1}{2}(S-\Delta Q) \quad s_{c}=\frac{1}{2}(S+\Delta Q)
$$

where $\Delta Q=Q_{o}-Q_{c}$. This result builds a direct link between the negotiation outcome and the quasi-rent difference. From Eqs. (1) and (2), the contractor's expected markup $\left(\pi_{a}\right)$ on the change order is

$$
\pi_{a}=\frac{s_{c}}{C}=\frac{1}{2 C}(v+\Delta Q)-\frac{1}{2}
$$

The term $v / C$ can be expressed as $1+\pi_{b}$, where $\pi_{b}$ is the ratio of the surplus from the change order to its construction cost. Substituting this expression into Eq. (3) yields

$$
\pi_{a}-\frac{\pi_{b}}{2}=\Delta \pi=\frac{\Delta Q}{2 C}
$$

where $\pi_{b} / 2$ is a rate of return corresponding to the $50: 50$ split. In the precontract stage, when nothing has been sunk, both parties have zero disagreement payoff, so $\pi_{b} / 2$ mimics the contractor's ex ante markup. It follows that the left side of Eq. (4) can be understood as an approximation of the excess markup $(\Delta \pi)$ that the contractor is able to charge under bilateral monopoly and in response to competition. From Eq. (4), the key hypothesis to be tested is that $\Delta \pi$ varies positively with $\Delta Q$.

Hypothesis

The greater the difference between the client's and the contractor's quasi-rent $(\Delta Q)$, the larger the difference between ex post and ex ante profit margin charged by the contractor.

\section{Empirical Design}

\section{Model}

As the concise form of Eq. (4) is derived by holding relevant factors constant, it is necessary to take these factors into consideration again in the empirical test. An effective strategy is to parameterize the effect of the change order's cost $(C)$; namely, that an econometric model can be set up as follows:

$$
\Delta \pi=\alpha_{0}+\alpha_{1} \Delta Q+X \beta
$$

where $X=$ row matrix for control variables and $\beta=$ column matrix for coefficients. By controlling for the influence of all relevant variables, the sign and coefficient of $\alpha_{1}$ can prove the validity of the hypothesis. In statistical terms,

$$
\begin{gathered}
H_{0}(\text { null hypothesis }): \alpha_{1}=0 \\
H_{1}(\text { alternative hypothesis }): \alpha_{1}>0
\end{gathered}
$$

\section{Measurement of Quasi-rents}

In empirical research design, the major challenge is the measurement of the explanatory variable $(\Delta Q$, the difference between the client's and contractor's quasi-rent). First, in the literature, the contractor's quasi-rent $\left(Q_{c}\right)$ is mainly made up of the ex ante profit margin and the value that would be lost if lump-sum fixed assets were deployed elsewhere (Chang 2013b). As the data collected in this study are from the city of Suzhou, in the Jiangsu province of China, there may be some local conditions to consider in estimating quasi-rent. The first element can be obtained by asking the respondent to provide the markup $(x)$ that has been factored into the bidding price. Regarding the second element, with reference to several consultations with local practitioners, in current Chinese practice, the rental contract of machines cannot be easily cancelled, and key management personnel dedicated to the project cannot be mobilized to other projects without incurring considerable cost should the contract terminate. It is sensible to treat the sum of these two costs as an upper-bound estimate of the contractor's quasi-rent. According to the cost breakdown of local construction projects published by the Suzhou Engineering Cost Association, an approximate estimate is about $5 \%$ of the contract value on average. Besides, the lock-in effect of the contractor's quasi-rent will decrease gradually as time passes, so

$$
Q_{c}=K \times \frac{(x+5)}{100} \times(1-y)
$$


where $K$ and $y$ indicate the contract value and the completion percentage, respectively.

Regarding the owner's quasi-rent, there are three significant elements: First, the opportunity cost of delay can be estimated approximately as the product of the average length of delay and the average opportunity cost of delay per day. The three local experts consulted in this study estimated that it would take an average of 30 days to retender the project with a daily hidden loss roughly equal to the capital spent on the contract per day $(K / T$, with $T$ being the project duration in days). Second, contractor replacement would entail extra expenses approximately equal to $8 \%$ of the contract value to cover repeated setup costs on site (e.g., costs for installing machines, temporary office, and management hardware such as computers). Third, the quality premium charged by the replacement contractor would incur roughly an extra cost of $5 \%$ of the contract value. The first and third elements are time-dependent, so the owner's quasi-rent can be expressed as

$$
Q_{o}=\frac{K}{T} \times 30 \times(1-y)+K \times 8 \%+K \times 5 \% \times(1-y)
$$

\section{Control Variables}

To insulate the effect of quasi-rent, seven control variables are considered in the empirical model. The variable names in bracket are the labels shown on the output table.

1. Relation (relation)

In TCE, one party's tendency to exploit the other party's vulnerability can be modeled as a probability problem (Tadelis and Williamson 2013). In the equilibrium of a one-shot game, the strategy of reaping short-term gain is mostly dominant over the strategy aiming for long-term benefit. However, in relational contracting, the potential future benefit would be factored into today's decision (Baker et al. 2002) and therefore enlarge the self-enforcing range of the contract (Klein 1996). To control for this factor, the respondent is asked to evaluate the closeness of relationship with the owner on a scale of 1 to 10 ; the higher the score, the stronger the contractor's tie with the owner.

2. Tendering method (tender)

The project procured through competitive tendering is coded as 1 ; otherwise, it is 0 .

3. Project value (l_projectsize)

Project value is measured by the logarithm of contract value in renminbi (RMB).

4. Project types (housing, office, factory, shop)

Projects are classified into five groups: residential, office, factory, retail, and other. Four dummy variables are created to control for this variable.

5. Types of change order (contingency, design_omission, design_change, policy_change)

Change orders under study are grouped into five types in accordance with the reasons of new order: contingency, design omission, design change, policy change, and others. Four dummies are created to capture the effect of this variable.

6. Occurrence time (occtime)

Occurrence time is measured by completion percentage when the change order takes place. For example, if a change order is issued in the second month of a 12-month project, this variable equals $0.17(2 / 12)$.

7. Pricing method (pricing_method)

Pricing method indicates the way that the price of change order is calculated; coded as 1 if the negotiation makes no reference to the original contract, and 0 if it is based on the original contract (e.g., unit rates).

\section{Data Collection}

To secure the return rate, all the data in this research were collected through questionnaire-based interviews. A total of 21 visits were made to 21 contractors to collect data concerning 62 change-order cases. Table 1 summarizes the 21 projects where these change orders took place. The average project value and duration were 22.44 million RMB and 249 days. The average expected profit margin was $5.6 \%$. The sample set contained a good balance of project types (residential project $29 \%$, office $9 \%$, factory $33 \%$, shop $5 \%$, and others $24 \%$ ). Design change (45\%) tops the list of changeorder reasons. Other reasons include contingency (21\%), design omission (16\%), policy change (11\%), and other (7\%). As reported in Table 2, the occurrence time of the change orders under study spanned all stages of the construction. The average ex post profit margin achieved is around $9.5 \%$, which is a premium of $3.9 \%$ relative to the average ex ante profit margin.

\section{Results}

The central prediction of the model presented in Eq. (4) is that the bargaining disadvantage facing the owner, as measured by the difference between her quasi-rent and the contractor's, would lead him or her to give away more ground to the contractor when negotiating a change order. It is hypothesized that the size of extra markup $(\Delta \pi)$ conceded relative to that which results from competition is proportional to the quasi-rent difference $(\Delta Q)$. Table 3 reports the ordinary least-squares (OLS) estimation of three econometric models that differ in the number of variables being controlled for. All estimates are robust for homoscedasticity using the function provided by the econometric software Stata 10.

In model $1, \Delta Q$ (measured in million $\mathrm{RMB}$ ) proves to be a statistically significant predictor for $\Delta \pi$ at a $95 \%$ confidence level with a coefficient of 0.00734 . It means that an increase of 1 million $\mathrm{RMB}$ in quasi-rent difference can lead to an extra markup of $0.73 \%$ being achieved by the contractor in postcontract negotiations. It is also interesting to look at the influence of control variables. First, it can be argued with a $95 \%$ confidence level that the contractor's

Table 1. Background Information of the Projects under Study

\begin{tabular}{lccc}
\hline Project number & $\begin{array}{c}\text { Project value } \\
\text { (million RMB) }\end{array}$ & Duration (days) & $\begin{array}{c}\text { Expected ex } \\
\text { ante markup (\%) }\end{array}$ \\
\hline Project 1 & 25.50 & 360 & 6 \\
Project 2 & 24.02 & 300 & 5 \\
Project 3 & 18.20 & 180 & 6 \\
Project 4 & 20.64 & 210 & 5 \\
Project 5 & 19.67 & 210 & 4 \\
Project 6 & 11.60 & 360 & 6 \\
Project 7 & 68.69 & 470 & 4 \\
Project 8 & 6.80 & 150 & 6 \\
Project 9 & 4.80 & 120 & 4 \\
Project 10 & 23.26 & 230 & 4 \\
Project 11 & 17.65 & 190 & 5 \\
Project 12 & 6.56 & 180 & 4 \\
Project 13 & 18.70 & 180 & 5 \\
Project 14 & 4.56 & 300 & 6 \\
Project 15 & 4.92 & 210 & 7 \\
Project 16 & 10.35 & 146 & 8 \\
Project 17 & 65.72 & 400 & 5 \\
Project 18 & 8.42 & 200 & 4 \\
Project 19 & 82.56 & 410 & 5 \\
Project 20 & 22.05 & 210 & 5.6 \\
Project 21 & 6.6 & 220 & 4 \\
Average & 22.44 & & 5 \\
\hline
\end{tabular}


Table 2. Summary of Change Orders

\begin{tabular}{|c|c|c|}
\hline $\begin{array}{l}\text { Change order } \\
\text { number }\end{array}$ & Occurrence time & Profit margin $(\%)$ \\
\hline 1 & 0.3 & 8 \\
\hline 2 & 0.8 & 10 \\
\hline 3 & 0.1 & 15 \\
\hline 4 & 0.15 & 10 \\
\hline 5 & 0.9 & 10 \\
\hline 6 & 0.2 & 7 \\
\hline 7 & 0.1 & 10 \\
\hline 8 & 0.8 & 15 \\
\hline 9 & 0.15 & 10 \\
\hline 10 & 0.5 & 7 \\
\hline 11 & 0.6 & 10 \\
\hline 12 & 0.2 & 7 \\
\hline 13 & 0.1 & 10 \\
\hline 14 & 0.8 & 10 \\
\hline 15 & 0.4 & 6 \\
\hline 16 & 0.9 & 5 \\
\hline 17 & 0.1 & 11 \\
\hline 18 & 0.1 & 5 \\
\hline 19 & 0.2 & 6 \\
\hline 20 & 0.15 & 6 \\
\hline 21 & 0.7 & 5 \\
\hline 22 & 0.1 & 14 \\
\hline 23 & 0.2 & 12 \\
\hline 24 & 0.4 & 15 \\
\hline 25 & 0.5 & 12 \\
\hline 26 & 0.7 & 14 \\
\hline 27 & 0.8 & 14 \\
\hline 28 & 0.2 & 14 \\
\hline 29 & 0.9 & 7 \\
\hline 30 & 0.1 & 9 \\
\hline 31 & 0.15 & 8 \\
\hline 32 & 0.8 & 10 \\
\hline 33 & 0.8 & 8 \\
\hline 34 & 0.1 & 9 \\
\hline 35 & 0.8 & 8 \\
\hline 36 & 0.9 & 5 \\
\hline 37 & 0.2 & 9 \\
\hline 38 & 0.9 & 6 \\
\hline 39 & 0.2 & 10 \\
\hline 40 & 0.4 & 8 \\
\hline 41 & 0.8 & 10 \\
\hline 42 & 0.3 & 12 \\
\hline 43 & 0.8 & 7 \\
\hline 44 & 0.2 & 16 \\
\hline 45 & 0.9 & 7 \\
\hline 46 & 0.2 & 12 \\
\hline 47 & 0.9 & 10 \\
\hline 48 & 0.2 & 15 \\
\hline 49 & 0.6 & 12 \\
\hline 50 & 0.8 & 10 \\
\hline 51 & 0.8 & 7 \\
\hline 52 & 0.2 & 11 \\
\hline 53 & 0.8 & 6 \\
\hline 54 & 0.8 & 8 \\
\hline 55 & 0.9 & 5 \\
\hline 56 & 0.1 & 10 \\
\hline 57 & 0.8 & 10 \\
\hline 58 & 0.9 & 9 \\
\hline 59 & 0.6 & 9 \\
\hline 60 & 0.1 & 10 \\
\hline 61 & 0.2 & 9 \\
\hline 62 & 0.8 & 6 \\
\hline Average & 0.48 & 9.45 \\
\hline
\end{tabular}

existing tie with the owner would lead the contractor to demand a smaller excess markup. Second, the ex ante use of competitive tendering reduces the magnitude of the excess margin achieved ex post. Third, the causes of change order may impinge upon the extent that an excessive profit margin can be achieved. As opposed to the contingency-induced change order, which has a negative effect on the excess profit margin, the contractor can charge a higher margin with change orders caused by design omission or policy change. But when more factors are controlled for in models 2 and 3, only contingency remains a significant variable. Generally, the result concerning the effect of change-order types should be read with caution. Further investigation is needed.

The variables contained in model 1 can explain $55 \%$ of the variations in $\Delta \pi$, which indicate the model fits the data reasonably well. It is also confirmed by the F-ratio test $(p<0.05)$. Models 2 and 3 are designed to check the stability of coefficient estimates when the more relevant variables occurrence time and pricing method are added to the model. The sign, coefficient, and significance level of $\Delta \pi$ remain stable, which lends credence to the robustness of the model. The study also conducted standard checks on multilinearity by computing the variance inflation factor (VIF), finding that the factor is fairly low (1.8) compared to the threshold value of 10 suggested by Chatterjee and Price (1991).

\section{Discussions and Implications}

The corroboration of the link between quasi-rent and the postcontract negotiation outcome has both theoretical and practical implications. In economics, quasi-rent has played a central role in explaining various contracting practices (Goldberg 1976; Klein et al. 1978; Klein and Leffler 1981; Williamson 1971). Governance structures should promote efficiency by securing the fair allocation of quasi-rents between parties (Crocker and Masten 1991; Zingales 1998). However, TCE empirical studies are mostly concerned with the reduced-form predictions; i.e., the causal relationship between transaction attributes and the governance structures chosen (Masten and Saussier 2000), leaving the core of the reasoning not empirically examined. At the center of transaction cost arguments lies a proposition that the magnitude of transaction cost is proportional to AQR (Gibbons 2005). The presence of AQR would intensify one party's tendency to seek an excessive price premium in postcontract negations with the vulnerable party, which is generally perceived as hostile and tends to trigger an aggressive pushback. The costly process of dispute resolution and its incidental effect on the ex ante incentive to investment, known as underinvestment problems (Grout 1984; Tirole 1986), are the main source of inefficiency. While transaction cost arguments have been so extensively investigated, there is still a lack of direct evidence about the predictive power of AQR for price premiums in postcontract negotiations. The finding of this research gives evidential support for the plausibility of this argument in the construction context.

The second implication is for the study of change orders. Making changes is not necessarily a bad thing in itself, as it could help achieve a better outcome after the resolution of risk. Where change orders are settled smoothly reflective of parties' bargaining power, as in the 62 change orders examined in the current study, the cost of a change order is limited to the price premium. There might be a tradeoff between ex ante investment in design development to avoid change orders and a price premium required for the same outcome through a change order ex post. Change orders arising from strategic considerations should be differentiated from those caused by design errors/omission. Ignorance of this distinction would result in so-called endogeneity problems, thus undermining 
Table 3. Results of Econometric Analysis

\begin{tabular}{|c|c|c|c|c|}
\hline Variable number & Variable name & Model 1 & Model 2 & Model 3 \\
\hline$X_{1}$ & $\Delta Q$ & $\begin{array}{c}\Delta \pi \\
0.00734^{\mathrm{a}} \\
(0.0035)\end{array}$ & $\begin{array}{c}\Delta \pi \\
0.00871^{\mathrm{a}} \\
(0.0036)\end{array}$ & $\begin{array}{c}\Delta \pi \\
0.00824^{\mathrm{a}} \\
(0.0037)\end{array}$ \\
\hline \multicolumn{5}{|l|}{ Control variable } \\
\hline$X_{2}$ & Relation & $\begin{array}{c}-0.00542^{\mathrm{a}} \\
(0.0024)\end{array}$ & $\begin{array}{c}-0.00564^{\mathrm{a}} \\
(0.0024)\end{array}$ & $\begin{array}{c}-0.00561^{\mathrm{a}} \\
(0.0024)\end{array}$ \\
\hline$X_{3}$ & Tender & $\begin{array}{r}-0.0170^{\mathrm{b}} \\
(0.0061)\end{array}$ & $\begin{array}{r}-0.0166^{\mathrm{b}} \\
(0.0060)\end{array}$ & $\begin{array}{r}-0.0154^{\mathrm{a}} \\
(0.0065)\end{array}$ \\
\hline$X_{4}$ & 1_projectsize & $\begin{array}{c}0.0126 \\
(0.0090)\end{array}$ & $\begin{array}{r}0.0157^{\mathrm{c}} \\
(0.0092)\end{array}$ & $\begin{array}{c}0.0144 \\
(0.0096)\end{array}$ \\
\hline \multicolumn{5}{|l|}{ Project type } \\
\hline$X_{5}$ & Housing & $\begin{array}{r}-0.00246 \\
(0.0083)\end{array}$ & $\begin{array}{r}-0.00211 \\
(0.0082)\end{array}$ & $\begin{array}{r}-0.00391 \\
(0.0090)\end{array}$ \\
\hline$X_{6}$ & Office & $\begin{array}{c}0.00474 \\
(0.0119)\end{array}$ & $\begin{array}{c}0.00505 \\
(0.0118)\end{array}$ & $\begin{array}{c}0.00260 \\
(0.0128)\end{array}$ \\
\hline$X_{7}$ & Factory & $\begin{array}{c}0.00119 \\
(0.0089)\end{array}$ & $\begin{array}{r}0.00171 \\
(0.0089)\end{array}$ & $\begin{array}{l}-0.00007 \\
(0.0096)\end{array}$ \\
\hline$X_{8}$ & Shop & $\begin{array}{r}-0.00682 \\
(0.0146)\end{array}$ & $\begin{array}{r}-0.00710 \\
(0.0144)\end{array}$ & $\begin{array}{r}-0.00709 \\
(0.0145)\end{array}$ \\
\hline \multicolumn{5}{|c|}{ Types of change order } \\
\hline$X_{9}$ & Contingency & $\begin{array}{r}-0.0213^{\mathrm{a}} \\
(0.0086)\end{array}$ & $\begin{array}{r}-0.0221^{\mathrm{a}} \\
(0.0086)\end{array}$ & $\begin{array}{r}-0.0233^{\mathrm{a}} \\
(0.0089)\end{array}$ \\
\hline$X_{10}$ & Design_omission & $\begin{array}{c}0.0270^{\mathrm{b}} \\
(0.0094)\end{array}$ & $\begin{array}{c}0.0183 \\
(0.0113)\end{array}$ & $\begin{array}{c}0.0176 \\
(0.0115)\end{array}$ \\
\hline$X_{11}$ & Design_change & $\begin{array}{r}-0.00167 \\
(0.0079)\end{array}$ & $\begin{array}{r}-0.00543 \\
(0.0082)\end{array}$ & $\begin{array}{r}-0.00540 \\
(0.0083)\end{array}$ \\
\hline$X_{12}$ & Policy_change & $\begin{array}{c}0.0254^{\mathrm{a}} \\
(0.0101)\end{array}$ & $\begin{array}{c}0.0220^{\mathrm{a}} \\
(0.0103)\end{array}$ & $\begin{array}{c}0.0175 \\
(0.0136)\end{array}$ \\
\hline$X_{13}$ & Occtime & & $\begin{array}{c}0.0136 \\
(0.0098)\end{array}$ & $\begin{array}{c}0.0142 \\
(0.0100)\end{array}$ \\
\hline$X_{14}$ & Pricing_method & & & $\begin{array}{r}-0.00479 \\
(0.0093)\end{array}$ \\
\hline & Constant & $\begin{array}{c}0.0197 \\
(0.0232)\end{array}$ & $\begin{array}{c}0.0225 \\
(0.0231)\end{array}$ & $\begin{array}{c}0.0248 \\
(0.0236)\end{array}$ \\
\hline & $N$ & 62 & 62 & 62 \\
\hline & $R^{2}$ & 0.550 & 0.567 & 0.569 \\
\hline
\end{tabular}

$$
\begin{aligned}
& { }^{\mathrm{a} p} p<0.05 . \\
& { }^{\mathrm{b}} p<0.01 . \\
& { }^{\mathrm{c}} p<0.1 .
\end{aligned}
$$

the reliability of coefficient estimates (Gulati and Nickerson 2008). In the current change orders study, where the statistical link is established between a set of explanatory variables (causes of change order) and the contract value increase, the importance of these causes is mainly determined by the coefficients' $p$-value. A crucial assumption of multiple regression models is that there is no correlation between explanatory variables and the error term (Wooldridge 2010). When this assumption does not hold, estimation of coefficients would be biased, making the $p$-value unreliable. This endogeneity problem would arise for three reasons: omitted variables, measurement error, or simultaneity (Hamilton and Nickerson 2003). A canonical example is whether smaller class size has led to an improvement in academic performance. The issue of simultaneity would be present because poor schools tend to get more funding from the government and thus have more resources to reduce class size (Stock and Watson 2003). The two-way interplay of the explained variable and the explanatory variables causes bias in statistical estimation. Endogeneity would also cast doubt on the reliability of the statistical results found in the literature of change orders, but for a different reason. It is generally accepted that the later the change is made, the greater its impact on the price increase (Ibbs 2005). This result is not as informative as it appears.
An analogy can be drawn to cancer. Late detection always takes considerably more resources to cure the disease. As a result, the real question is why change orders are made so late. Is it purely a matter of uncertainty, or is it also involved with a strategic choice? There might be an economic argument that change orders should not be entirely avoided ex ante because the extra price paid for a change order could be cheaper than the cost entailed at the outset to completely prevent it. Omission of this factor in the model would yield endogeneity problems. For example, according to Serag et al. (2010), quantity differences, unforeseen work, and design that is unfit for operational requirements are all found as significant causes for change orders. However, these factors have one thing in common: they may all be affected by the choice of design incompleteness. Without taking this factor into account, the effect of these factors would be overestimated in econometric models (i.e., it would be an insignificant variable mistakenly judged to be significant). An instrumental way of advancing the studies of change orders is through the development of a behavioral model that is sophisticated enough to capture the effect of strategic contractual incompleteness on change orders, whereby the endogeneity bias can be corrected in future empirical investigations into change orders. This suggestion also echoes the key insight of 
Bajari and Tadelis (2001) that design incompleteness is an endogenous variable for the transaction cost of construction procurement.

The third implication is associated with dispute resolution. In the 62 change-order cases, the agreements over price were reached in a relatively smooth way, generally in line with the bargaining power of two parties. The bargaining solutions can serve as useful reference points for postcontract negotiations. Acknowledging the presence of bargaining power imbalance between the owner and the contractor would help both parties take a more realistic stance towards the settlement of disputes. The establishment of the "fair" price with consideration of bargaining power from the outset should be beneficial to the management of disputes. There is growing evidence from behavioral economics that the perception of "status quo" (Kahneman 1992; Kahneman et al. 1991) and "fairness" (Bartling 2011) could be crucial in shaping people's decisions. Further effort can be built upon the current research to explore the effect of these behavioral factors on the severity of holdup problems. Moreover, a careful consideration of bargaining position can help the owner get her way with low transaction costs. For example, in formulating a strategy for dealing with the contractor, the owner can choose to act more wisely in deciding when to push hard with requirements and when to turn a blind eye to slightly substandard output by considering his or her bargaining position at that time.

\section{Limitations and Suggestions for Future Studies}

The theoretical prediction of this research has general applicability, but the empirical study has limitations. First, three simplifying assumptions are made in the quasi-rent formulas: the contractor's sunk cost (5\% of the project value), the time needed for retender (30 days), and the risk premium required by the replacement contractor ( $8 \%$ of the project value). These figures are based on the average of evaluations from three senior local experts and are assumed to be invariant across all projects. For this invariability assumption to work, the project with a maximum value of 100 million RMB and containing low technical complexity was chosen. This strategy is chosen because the pilot study found that respondents could not provide reliable estimates in interviews. For the purpose of this research, it seems to be an effective strategy, but these assumptions can be improved upon through development of formal models. For example, the price premium can be estimated using a bidding model. However, as seen in the existing models (Criesmer et al. 1967; McAfee and McMillan 1986), this entails estimation of numerous parameters, which inevitably creates considerable difficulty in data collection. Hopefully, the emergence of big data studies and the growing application of building information modeling techniques would make it feasible to estimate relevant parameters reliably in the future.

Second, the size of the sample set analyzed in this research is limited by the sensibility of the information requested from the main contractor. Around half of the contractors approached in this study were put off for this reason. As cost-estimating practices would affect how markups are calculated by individual contractors, local cost engineering associations for referral were considered. While sampling bias arising from selective participation of contractors in the current study is benign, it seems useful in the future to test the core hypothesis of this research in broader national and international contexts.

Third, linear quasi-rents formulas [e.g., Eqs. (6) and (7)] have particular strength in analyzing the data collected from fieldworks. However, the effect of nonlinearity should not be precluded.
As seen in the study of incentive contracts, addressing this issue requires a different approach, such as experimental methods and simulation-based methods (Basu and Kalyanaram 1990). This topic is worth further exploration.

\section{Conclusions}

This research makes a first attempt to draw on the Nash bargaining model to derive the relationship between quasi-rent difference and excess profit margin in the pricing of change orders and put this theoretical prediction to an empirical test on the basis of 62 change orders from 21 projects using econometric models. The owner's postcontract bargaining disadvantage manifests itself in the higher profit margin paid for change orders. This finding lends credence to the central proposition taken in the analysis of construction holdup problems that the owner is vulnerable in postcontract negotiations. This finding brings to the foreground the significance of recognizing that change orders might result from the owner's strategic choice. Ignorance of this factor would lead to an overestimation of the statistical importance of alleged change-order causes (e.g., extra work). An important way of advancing the existing studies of change orders is to develop a behavioral model that accommodates this factor.

\section{References}

Aghion, P., Dewatripont, M., and Rey, P. (1994). "Renegotiation design with unverifiable information." Econometrica J. Econometric Soc., 62(2), 257-282.

Bajari, P., and Tadelis, S. (2001). "Incentives versus transaction costs: A theory of procurement contracts." RAND J. Econ., 32(3), 387-407.

Baker, G., Gibbons, R., and Murphy, K. J. (2002). "Relational contracts and the theory of the firm." Q. J. Econ., 117(1), 39-84.

Bartling, B. (2011). "Relative performance or team evaluation? Optimal contracts for other-regarding agents." J. Econ. Behav. Organiz., 79(3), 183-193.

Basu, A. K., and Kalyanaram, G. (1990). "On the relative performance of linear versus nonlinear compensation plans." Int. J. Res. Market., 7(2-3), 171-178.

Binmore, K., Rubinstein, A., and Wolinsky, A. (1986). "The Nash bargaining solution in economic modelling." Rand J. Econ., 17(2), 176-188.

Chang, C. Y. (2013a). "A critical analysis of recent advances in the techniques for the evaluation of renewable energy projects." Int. J. Proj. Manage., 31(7), 1057-1067.

Chang, C. Y. (2013b). "Understanding the hold-up problem in the management of megaprojects: The case of the Channel Tunnel Rail Link project." Int. J. Proj. Manage., 31(4), 628-637.

Chang, C. Y. (2013c). "When might a project company break up? The perspective of risk-bearing capacity." Constr. Manage. Econ., 31(12), 1186-1198.

Chang, C. Y. (2014). "Principal-agent model of risk allocation in construction contracts and its critique." J. Constr. Eng. Manage., 10.1061/ (ASCE)CO.1943-7862.0000779, 04013032.

Chang, C. Y., and Ive, G. (2003). "Discussion of "Model for understanding, preventing, and resolving project disputes" by Panagiotis Mitropoulos and Gregory Howell." J. Constr. Eng. Manage., 10.1061/(ASCE)0733 $-9364(2003) 129: 2(231), 231-232$.

Chang, C. Y., and Ive, G. (2007a). "Reversal of bargaining power in construction projects: Meaning, existence, and implications." Constr. Manage. Econ., 25(8), 845-855.

Chang, C. Y., and Ive, G. (2007b). "The hold-up problem in the management of construction projects: A case study of the Channel Tunnel." Int. J. Proj. Manage., 25(4), 394-404.

Chatterjee, S., and Price, B. (1991). Regression analysis by example, 2nd Ed., Wiley, New York. 
Chung, T.-Y. (1991). "Incomplete contracts, specific investments, and risk sharing." Rev. Econ. Stud., 58(5), 1031-1042.

Criesmer, J. H., Levitan, R. E., and Shubikt, M. (1967). "Toward a study of bidding processes. Part IV-Games with unknown costs." Naval Res. Logist. Q., 14(4), 415-433.

Crocker, K. J., and Masten, S. E. (1991). "Pretia ex machina-prices and process in long-term contracts." JL Econ., 34(1), 69-99.

Farrell, J. (1987). "Information and the Coase theorem." J. Econ. Perspect., 1(2), 113-129.

Finkel, G. (1997). The economics of the construction industry, ME Sharpe, New York.

Gibbons, R. (2005). "Four formal (izable) theories of the firm?" J. Econ. Behav. Organiz., 58(2), 200-245.

Goldberg, V. P. (1976). "Toward an expanded economic theory of contract." J. Econ. Issues, 10(1), 45-61.

Grossman, S. J., and Hart, O. D. (1986). "The costs and benefits of ownership: A theory of vertical and lateral integration." J. Political Econ., 94(4), 691-719.

Grout, P. A. (1984). "Investment and wages in the absence of binding contracts: A Nash bargaining approach." Econometrica J. Econometric Soc., 52(2), 449-460.

Gulati, R., and Nickerson, J. A. (2008). "Interorganizational trust, governance choice, and exchange performance." Organiz. Sci., 19(5), 688-708.

Hamilton, B. H., and Nickerson, J. A. (2003). "Correcting for endogeneity in strategic management research." Strategic Organiz., 1(1), 51-78.

Hart, O. (1995). Firms, contracts, and financial structure, Clarendon Press, Oxford, England.

Hermalin, B. E., and Katz, M. L. (1991). "Moral hazard and verifiability: The effects of renegotiation in agency." Econometrica J. Econometric Soc., 59(6), 1735-1753.

Hsieh, T. Y., Lu, S. T., and Wu, C. H. (2004). "Statistical analysis of causes for change orders in metropolitan public works." Int. J. Proj. Manage., 22(8), 679-686.

Ibbs, W. (2005). "Impact of change's timing on labor productivity." J. Constr. Eng. Manage., 10.1061/(ASCE)0733-9364(2005)131: 11(1219), 1219-1223.

Ive, G., and Chang, C. Y. (2007). "The principle of inconsistent trinity in the selection of procurement systems." Constr. Manage. Econ., 25(7), 677-690.

Kahneman, D. (1992). "Reference points, anchors, norms, and mixed feelings.” Organiz. Behav. Human Decis. Processes, 51(2), 296-312.

Kahneman, D., Knetsch, J. L., and Thaler, R. H. (1991). "Anomalies: The endowment effect, loss aversion, and status quo bias." J. Econ. Perspect., 5(1), 193-206.

Klein, B. (1996). "Why hold-ups occur: The self-enforcing range of contractual relationships." Econ. Inquiry, 34(3), 444-463.

Klein, B., Crawford, R. G., and Alchian, A. A. (1978). "Vertical integration, appropriable rents, and the competitive contracting process." J. Law Econ., 21(2), 297-326.

Klein, B., and Leffler, K. B. (1981). "The role of market forces in assuring contractual performance.” J. Political Econ., 89(4), 615-641.
Latham, M. (1994). Constructing the team: Final report of the government/ industry review of procurement and contractual arrangements in the UK construction industry, The Stationery Office, London.

Macher, J. T., and Richman, B. D. (2008). "Transaction cost economics: An assessment of empirical research in the social sciences." Bus. Politics, 10(1), 1-65.

Masten, S. E., Meehan, J. W., and Snyder, E. A. (1991). "The costs of organization." J. Law Econ. Organiz., 7(1), 1-25.

Masten, S. E., and Saussier, S. (2000). "Econometrics of contracts: An assessment of developments in the empirical literature on contracting." Revue d'économie Industrielle, 92(1), 215-236.

McAfee, R. P., and McMillan, J. (1986). "Bidding for contracts: A principal-agent analysis." Rand J. Econ., 17(3), 326-338.

Milgrom, P., and Roberts, J. (1992). Economics, organization, and management, Prentice-Hall, Englewood Cliffs, NJ.

Mitropoulos, P., and Howell, G. (2001). "Model for understanding, preventing, and resolving project disputes." J. Constr. Eng. Manage., 10.1061/(ASCE)0733-9364(2001)127:3(223), 223-231.

Nash, J. F. (1950). "The bargaining problem.” Econometrica, 18(2), $155-162$.

Serag, E., Oloufa, A., Malone, L., and Radwan, E. (2010). "Model for quantifying the impact of change orders on project cost for US roadwork construction." J. Constr. Eng. Manage., 10.1061/(ASCE)CO .1943-7862.0000206, 1015-1027.

Shelanski, H. A., and Klein, P. G. (1995). "Empirical research in transaction cost economics: A review and assessment." J. Law Econ. Organiz., 11(2), 335-361.

Stata 10 [Computer software]. College Station, TX, StataCorp.

Stock, J. H., and Watson, M. W. (2003). Introduction to econometrics, Addison Wesley, Boston.

Sun, M., and Meng, X. (2009). "Taxonomy for change causes and effects in construction projects." Int. J. Proj. Manage., 27(6), 560-572.

Tadelis, S., and Williamson, O. E. (2013). "Transaction cost ecoomics." Handbook of organizational economics, R. Gibbons and J. Roberts, eds., Princeton University Press, Princeton, NJ, 159-189.

Tirole, J. (1986). "Procurement and renegotiation." J. Political Econ., 94(2), 235-259.

Unsal, H. I., and Taylor, J. E. (2010). "Modeling interfirm dependency: Game theoretic simulation to examine the holdup problem in project networks." J. Constr. Eng. Manage., 10.1061/(ASCE)CO.1943-7862 .0000286, 284-293.

Williamson, O. E. (1971). "The vertical integration of production: Market failure considerations." Am. Econ. Rev., 61(2), 112-123.

Williamson, O. E. (2010). "Transaction cost economics: The natural progression.” Am. Econ. Rev., 100(3), 673-690.

Winch, G. M. (2001). "Governing the project process: A conceptual framework." Constr. Manage. Econ., 19(8), 799-808.

Wooldridge, J. M. (2010). Econometric analysis of cross section and panel data, MIT Press, Cambridge, MA.

Wu, C.-H., Hsieh, T.-Y., and Cheng, W.-l. (2005). "Statistical analysis of causes for design change in highway construction on Taiwan." Int. J. Proj. Manage., 23(7), 554-563.

Zingales, L. (1998). Corporate governance, The new palgrave dictionaiy of economics and the law, Macmillan, London, 497-502. 